\title{
RELASI KUASA MEDIA DAN ISU GENDER DALAM PROGRAM TELEVISI DI INDONESIA
}

\author{
Catur Nugroho ${ }^{1}$ \\ ${ }^{1}$ Telkom University
}

\begin{abstract}
ABSTRAK
Media saat ini bukan lagi sebagai media penyampai pesan (mediasi) tetapi telah menjadi media yang mempengaruhi opini dan sikap masyarakat (mediatisasi). Media massa akan bergerak dinamis diantara pusaran-pusaran kepentingan yang sedang bermain, baik kepentingan ekonomi, sosial maupun politik. Media di Indonesia banyak dikuasai konglomerat media yang memiliki banyak perusahaan media dalam berbagai platform, baik berupa media mainstream maupun media baru. Hanya sedikit media di Indonesia yang merupakan perusahaan media diluar konglomerasi media, salah satunya adalah media televisi NET.TV. di tengah persaingan bisnis media di Indonesia yang sangat ketat, NET.TV hadir memberikan warna baru dalam dunia pertelevisian dengan mengusung semangat anak muda dan generasi masa kini. Penelitian ini menganalisis salah satu program acara NET.TV yang merupakan program talkshow, yaitu Satu Indonesia, episode Sultan Hamengkubuwono X. Dengan menggunakan metode analisis wacana kritis model Norman Fairclough, penelitian ini mencoba membongkar wacana tentang feminisme yang dikonstruksi NET.TV dalam tayangan programnya. Dari berbagai alat kebahasaan yang digunakan NET.TV dalam program acara dialog "Satu Indonesia" episode Sultan hamengku Buwono X, terdapat tiga alat yang menandai representasi tokoh yang terlibat dalam acara ini. Hasil penelitian menunjukkan bahwa aspek kebahasaan berupa diksi, penggunaan kalimat, dan pemilihan tata bahasa yang digunakan NET.TV telah menempatkan tema mengenai suksesi kepemimpinan di Yogyakarta yang berkaitan dengan isu kesetaraan gender sebagai sesuatu yang tak perlu dirisaukan seluruh kalangan masyarakat. Selain itu aspek kebahasaan juga telah menempatkan tokoh Sultan dan institusi keraton dan Gubernur dalam representasi yang positif. Hal ini erat kaitannya dengan penggunaan bahasa dan penguasaan wacana menjadi alat bagi penguasa untuk melanggengkan hegemoninya.
\end{abstract}

Kata-kata Kunci: Analisis Wacana Kritis; Media; Gender; Relasi Kuasa; Televisi

\section{POWER RELATION AND GENDER ISSUE IN INDONESIA TELEVISION PROGRAM}

\begin{abstract}
Today's media is no longer as a medium for delivering messages (mediation) but has become a medium that influences people's opinions and attitudes (mediation). The mass media moves dynamically among the various interests played, both economic, social and political interests. Media in Indonesia is dominated by media conglomerates that have many media companies in various platforms, both in the form of mainstream media and new media. In the midst of a very tight competition in the media business in Indonesia, NET.TV present to provide a new color in the television world by carrying the spirit of young people and the present generation. This study analyzes one of the NET.TV program programs which is a talkshow program, Satu Indonesia, episode of Sultan Hamengkubuwono X. Using Norman Fairclough's model of critical discourse analysis (CDA), this study tries to uncover the discourse about power relation and feminism constructed by NET.TV in its program impressions. From the various linguistic tools used by NET.TV in the "One Indonesia" dialogue program episode of Sultan Hamengku Buwono X, there are three tools that mark the representation of figures involved in this event. The results show that linguistic aspects in the form of diction, sentence usage, and grammar selection used by NET.TV have placed the theme of the succession of leadership in Yogyakarta relating to the issue of gender equality as something that does not need to be bothered by the whole community. In addition, linguistic aspects have also placed the Sultan's character and the palace institution and the Governor in a positive representation. This is closely related to the use of language and mastery of discourse is a tool for the authorities to perpetuate their hegemony.
\end{abstract}

Keywords: Critical Discourse Analysis; Gender; Media; Power Relation; Television

Korespondensi: Catur Nugroho. Telkom University, Jl. Telekomunikasi No. 1, Bandung 40288

Email:mas_pires@yahoo.com 


\section{PENDAHULUAN}

Media saat ini bukan lagi sebagai media penyampai pesan (mediasi) tetapi telah menjadi media yang mempengaruhi opini dan sikap masyarakat (mediatisasi). Hal ini lah yang akhirnya memunculkan bias media, dimana media yang seharusnya menjadi pilar keempat dari sebuah negara demokrasi dengan menyuarakan kepentingan masyarakat, justru menjadi pihak yang memiliki kepentingan ekonomi dan politik tersendiri. Konstruksi media atas realitas yang terjadi di dalam kehidupan sosial tidak berada di dalam ruang hampa yang terlepas dari berbagai kepentingan. Althusser menyampaikan bahwa media sesungguhnya berada di tengah realitas sosial yang sarat dengan berbagai kepentingan, konflik, dan fakta yang kompleks dan beragam.

Media massa bukan lembaga yang bebas dan independen tetapi terkait dengan realitas sosial pada berbagai kepentingan yang bermain dalam media. Media massa senantiasa bergerak dinamis diantara pusaran-pusaran kepentingan yang sedang bermain, baik kepentingan ekonomi, sosial maupun politik. Kenyataan ini menyebabkan bias berita di media massa adalah sesuatu yang sulit dihindari, apalagi dengan terjadinya konglomerasi media oleh segelintir penguasa yang sekaligus adalah pemilik kuasa. Media massa memiliki peran yang penting dalam menyampaikan berita, penilaian atau gambaran umum tentang banyak hal yang dapat membentuk opini publik dan menggambarkan citra terepresentasikan untuk diletakkan dalam kehidupan yang lebih empiris.

Media baru, internet dengan berbagai variannya, di Indonesia saat ini mengalami perkembangan sangat pesat, sehingga masyarakat mengalami keberlimpahan informasi. Namun dengan jumlah penduduk yang lebih dari 260 juta jiwa, belum seluruh lapisan masyarkat tersentuh oleh media baru tersebut. Masih banyak masyarakat Indonesia yang menggunakan media massa mainstream saat ini, terutama televisi.

Televisi saat ini masih menjadi media utama yang dikonsumsi masyarakat Indonesia yaitu sebesar 95\%, disusul oleh interNET 33\%, radio $20 \%$, surat kabar $12 \%$, tabloid $6 \%$, dan majalah 5\% (Nielsen, 2014). Hal tersebut menunjukkan bahwa televisi memiliki audience terbesar sehingga memiliki peran yang penting dalam menciptakan persepsi tentang peran yang dimainkan oleh televisi mengenai pengembangan kehidupan sosial, ekonomi dan politik dalam masyarakat.

Keunggulan media televisi siaran bebas (free to air) yang tidak dimiliki oleh media arus utama lainnya adalah konten yang ada di dalamnya, baik berupa informasi, hiburan maupun opini yang dipublikasikan atau disiarkan kepada khalayaknya secara gratis.

Salah satu televisi nasional yang cukup berkembang meskipun belum lama berdiri adalah NET.TV. Televisi swasta yang memiliki slogan sebagai "Televisi Masa Kini" dan memiliki sapaan untuk para penontonnya 
sebagai good people ini, berusaha merebut hati masyarakat Indonesia dengan menyajikan program-program acara yang cukup kreatif dengan ide-ide segar. Salah satu misi yang ditargetkan NET.TV pada awal terbentuknya adalah agar masyarakat dapat memilah informasi yang dapat dipercaya secara objektif sehingga dapat membangun opini yang positif terhadap suatu hal sesuai dengan realitas yang sedang terjadi.

Program "Satu Indonesia" adalah salah satu program tayangan talkshow yang menghadirkan tema tertentu dalam setiap episodenya. Program acara ini ditujukan untuk dapat mengungkapkan suatu kebenaran dalam sebuah konflik yang sedang terjadi di kehidupan masyarakat. Dengan menghadirkan narasumber yang beragam, mulai dari para tokoh politik, kepala daerah, olahragawan, CEO perusahaan, hingga presiden Joko Widodo, menjadikan acara ini dapat bertahan hingga saat ini.

Salah satu permasalahan yang sempat dibahas dalam program acara Satu Indonesia yaitu mengenai konflik yang terjadi di Keraton Yogyakarta pada episode Sri Sultan Hamengkubuwono X. Pada episode ini, Gubernur Daerah Istimewa Yogyakarta yang sekaligus raja Keraton Yogyakarta menjadi narasumber utama. Selain itu juga menampilkan GKR Hemas, istri Sultan dan GKR Pembayun, putri tertua Sultan sebagai narasumber tamu.

Konflik internal yang terjadi di Keraton Yogyakarta yang dibahas dalam talkshow "Satu Indonesia" di NET TV menarik untuk dianalisis. Hal ini dikarenakan pemberitaan konflik internal di Keraton Yogyakarta dikupas melalui pihak yang diduga selama ini menjadi penyebab asal mulanya konflik tersebut yaitu Sri Sultan Hamengkubuwono X. Dalam episode ini, Satu Indonesia mencoba mengungkap berbagai fakta berkaitan dengan konflik tersebut dari berbagai sisi, termasuk dari sudut pandang kesetaraan gender dan feminisme.

Secara garis besar, talkshow "Satu Indonesia" episode Sultan Hamengkubuwono X ini menggambarkan mengenai kuatnya tokoh Sultan sebagai panutan dalam kehidupan di Keraton Yogyakarta dan kentalnya kebudayaan yang diajarkan oleh Keraton di Yogyakarta untuk tetap melestarikan budaya warisan para leluhur.

Dalam episode ini juga dibahas tentang bagaimana posisi perempuan dalam sistem kepemimpinan dan kekuasaan Jawa. Dimana selama ini perempuan di jawa khususnya, dan di Indonesia pada umumnya, masih sekedar sebagai pelengkap bagi pria, dan cenderung di bawah dominasi dan hegemoni laki-laki.

Dengan posisi Yogyakarta sebagai salah satu provinsi istimewa di Indonesia, dimana Gubernur Daerah Istimewa Yogyakarta adalah Sultan yang bertahta di Keraton Yogyakarta dan Wakil Gubernur DIY adalah pemegang kekuasaan Puro Pakualaman, menjadikan posisi Raja Yogyakarta sangat penting dan istimewa. Karena raja Keraton Yogyakarta yang sekaligus Gubernur DIY adalah pemegang kekuasaan politik sekaligus kultural di wilayah Yogyakarta.

Adanya konflik internal yang terjadi di Keraton Yogyakarta dipicu oleh isu sensitif tentang pergantian raja Keraton Yogyakarta 
sekaligus Gubernur Yogyakarta. Hal ini menjadi permasalahan tersendiri, karena Sultan Hamengkubuwono X sebagai raja yang bertahta tidak mempunyai anak laki-laki sebagai putra mahkota dan pewaris tahta keraton Yogyakarta. Sebagai kerajaan Mataran Islam, Keraton Yogyakarta selama ini dipimpin oleh seorang laki-laki dengan gelar Sri Sultan Hamengkubuwono yang berkuasa sekaligus sebagai pemimpin rakyat Yogyakarta dan pemimpin agama. Sehingga ketika Sultan HB X tidak memiliki anak laki-laki, sebagian kerabat dan bangsawan Keraton Yogyakarta berpendapat bahwa adik Sultan HB X yang berhak menjadi pewaris tahta keraton Yogyakarta. Namun sebagian yang lain tidak mempermasalahkan jika putri tertua Sultan HB X, GKR Pembayun menjadi penerus tahta di Yogyakarta menggantikan Sultan Hamengkubuwono X.

Konflik internal Keraton Yogyakarta tersebut semakin meruncing ketika Sri Sultan Hamengkubuwono $X$ mengeluarkan sabda pertama yang berisi 5 poin pada 30 April 2015. Sabda tersebut memiliki poin-poin yang pertama yaitu mengenai penggantian nama Sri Sultan Hamengkubuwono menjadi Sri Sultan Hamengkubawono, kedua yaitu gelar sultan tentang khalifatullah dihapuskan, ketiga yaitu penyebutan kaping sedasa diganti kaping sapuluh, keempat yaitu mengubah perjanjian antara pendiri $\mathrm{Ki}$ Ageng Giring dengan $\mathrm{Ki}$ Ageng Pemanahan dan yang terakhir yaitu mengenai menyempurnakan keris Kanjeng
Kyai Kopek dengan Kanjeng Kyai Ajeng Piturun.

Sabda raja ini kemudian diperkuat dengan adanya sabda kedua yang dikeluarkan oleh Sri Sultan Hamengkubuwono X mengenai perubahan nama anak pertamanya Gusti Kanjeng Ratu (GKR) Pembayun menjadi GKR Mangkubumi. Perubahan nama putri sulungnya ini juga diikuti dengan diangkatnya menjadi putri mahkota. Sultan sendiri mengakui secara implisit, bahwa perubahan nama dan strata kesultanan GKR Pembayun merupakan indikasi kuat putri sulungnya itu bakal menjadi penerus takhta keraton Yogyakarta, sekaligus penerus jabatan Gubernur Daerah Istimewa Yogyakarta. Sabda Raja kedua itulah yang akhirnya membuat keluarga besar keraton Yogyakarta pecah. Banyak adik-adik Sultan tidak dapat menerima Pembayun jadi Putri Mahkota yang bakal memimpin Yogyakarta.

Konflik internal keraton Yogyakarta terkait isu suksesi kepemimpinan ini pada akhirnya bersinggungan dengan isu feminisme, dimana perjuangan persamaan hak antara lakilaki dan perempuan dalam segala bidang kehidupan, termasuk dalam ranah politik dan kekuasaan.

Hal ini menjadi sangat menarik untuk diteliti dengan pendekatan wacana dimana bahasa bergantung pada gambaran atau pikiran orang dalam hubungannya dengan isyarat dan objek yang di isyaratkan. Bagaimana media, dalam hal ini, NET.TV merepresentasikan isu gender di dalam tayangan talkshow dan 
bagaimana makna itu diciptakan melalui bahasa dan wacana yang disampaikan dalam ruang lingkup sistem kerajaan di Keraton Yogyakarta mengenai isu gender.

Dari latar belakang masalah di atas, maka tema penelitian ini adalah tentang relasi kuasa media dan isu gender dalam isu suksesi kepemimpinan di Yogyakarta. Penelitian ini bertujuan mengungkap dan menganalisis bagaimana isu kesetaraan gender dalam isu suksesi kepemimpinan di Yogyakarta direpresentasikan melalui Talkshow "Satu Indonesia" NET.TV Episode Sri Sultan Hamengkubuwono X. Penelitian ini juga bertujuan untuk mengetahui aspek kebahasaan yang digunakan NET.TV untuk merepresentasikan suksesi kepemimpinan di Yogyakarta, dan bagaimana hubungan antara ideologi media dan aspek kebahasaan yang dihasilkan dalam merepresentasikan kuasa media dan isu gender dalam konteks suksesi kepemimpinan di Yogyakarta. Juga untuk mengetahui situasi sosial, politik, dan budaya apa yang melatarbelakangi aspek ke-bahasaan yang digunakan untuk merepresentasikan feminisme dalam konteks suksesi kepemimpinan di Yogyakarta.

\section{TINJAUAN PUSTAKA}

\section{Media dan Kekuasaan}

Penyiaran televisi dianggap terlalu memiliki pengaruh yang kuat untuk jatuh ke tangan kepentingan tertentu tanpa batasan jelas dalam melindungi publik dari bahaya atau manipulasi yang potensial. Televisi sebagai saluran komunikasi massa dianggap hampir tidak pernah menayangkan sesuatu yang sesuai dengan realitas sesungguhnya. Hampir semua televisi menayangkan realitas tangan kedua, dimana selalu ada setting cerita yang dimainkan dengan potensi manipulasi yang cukup tinggi. Televisi juga dianggap sebagai pemberi informasi publik yang tidak informal, namun secara umum tetap dapat dipercaya (McQuail, 2011).

Peranan lain media televisi adalah sebagai pengajar bagi anak-anak di sekolah dan orang dewasa di rumah. Sebuah ciri yang bertahan dari daya tarik televisi terletak pada fakta bahwa televisi merupakan media yang menyatukan orang untuk berbagi pengalaman yang sama dalam masyarakat yang terbagi-bagi dan individual keluarga. Sebagaimana disampaikan Maulana dan Nugroho bahwa media massa (dalam hal ini televisi) adalah faktor lingkungan yang mengubah perilaku khalayak melalui proses pelaziman klasik, pelaziman operan, atau proses imitasi (Maulana \& Nugroho, 2018).

Penemuan genre utama dari televisi bermula dari kemampuannya untuk menyiarkan banyak gambar dan suara secara langsung, dan kemudian bertindak sebagai 'jendela dunia' dalam waktu yang riil. Bahkan, studio produksi melakukan siaran langsung sebelum munculnya teknik rekaman video yang efisien. Kemampuan ini secara stimultan telah dibatasi untuk konten tertentu, termasuk acara olahraga, siaran berita, dan beberapa jenis hiburan. Kebanyakan konten televisi tidak langsung, walaupun tujuannya adalah untuk menciptakan ilusi adanya realitas yang sedang berlangsung (McQuail, 2011). 
Dalam siaran berita, televisi yang memiliki keunggulan kecepatan dibandingkan media cetak, dan mampu melakukan kapitalisasi pelaporan peristiwa dengan mengembangkan berbagai varian program berita yang diolah menjadi sebuah pertunjukan. Selain itu, genre program televisi yang sampai saat ini masih dapat bertahan adalah program talkshow yang memberikan tayangan tentang gosip, skandal, dan informasi sehari-hari yang semua bercampur menjadi satu.

Idealnya setiap media yang menyajikan secara keseluruhan acara, namun pada kenyataannya banyak penelitian yang membuktikan bahwa konten media tidak selalu mencerminkan realitas sosial yang sesungguhnya. Media senantiasa berhubungan dengan ideologi yang dibangun. Media saat ini tidak harus mengikuti nilai kebutuhan masyarakat, tetapi kebutuhan elite media. Produksi berita di media massa pada dasarnya adalah penyusunan realitas untuk membentuk sebuah "cerita".

Menurut McQuail (2011) kondisi kekuatan media yang efektif secara umum termasuk pada kemampuan industri media nasional dalam menjangkau sebagian besar populasi, tingkat kesepahaman dalam pesan yang disebarkan (kemanapun arahnya), dan penilaian atas kredibilitas dan kepercayaan media oleh khalayak (McQuail, 2011).

Media selalu berhubungan dalam satu dan lain hal dengan struktur kekuatan politik dan ekonomi yang kuat. Nyatanya, media yang memiliki nilai ekonomi adalah objek kompetisi bagi kontrol dan akses. Kedua, media tunduk pada peraturan politik, ekonomi, dan hukum. Ketiga, media massa secara umum dipandang sebagai instrumen efektif bagi kekuasaan dengan kapasitas potensial untuk membawa pengaruh dengan berbagai cara. Keempat, kekuatan media massa tidak dengan rata tersedia untuk semua kelompok atau kepentingan.

McQuail (2011) menyampaikan bahwa terdapat dua model dalam kekuatan media yaitu model media dominan (model of dominant media) yaitu media sebagai kekuatan yang mewakili lembaga kuat lainnya dan model pluralis (pluralist media) yang memungkinkan lebih banyak keragaman dan kemungkinan, tidak ada elit yang dominan atau satu, dan perubahan serta kontrol demokratis mungkin terjadi (McQuail, 2011).

Komunikasi atau kekuatan simbolik berbeda dengan kekuatan jenis lain karena tidak menggunakan faktor non-material (kepercayaan, rasionalisasi, penghargaan, kasih sayang, dan lain-lain). Adapun tipe-tipe utama dalam menggunakan kekuatan simbolik pada kekuasaan komunikasi yaitu dengan cara informasi, menstimulasi aksi, mengarahkan perhatian secara berbeda, persuasi, mendefinisikan situasi dan memberikan kerangka terhadap dunia nyata (McQuail, 2011).

Dalam beberapa keadaan (terutama dalam hal kurangnya dan lemahnya pertahanan 
terhadap efek), banyak efek media terjadi sebagai hasil mendefinisikan suatu situasi dan framing pada dunia nyata, penentuan informasi dan pembedaan arah perhatian (termasuk penguraian ide atau citra tertentu) daripada persuasi atau simulasi aksi.

\section{Perempuan dan Media}

Dalam industri media, pesan di dalamnya termasuk produksi dan distribusi informasi sering menjadi topik yang tiada akhir. Media dan pekerja media tidak dapat lepas dari industri dan kapitalisasi media yang terus berlangsung dalam dialektika kehidupan sepanjang masa. Penelitian ini fokus pada bagaimana media televisi mengangkat isu tentang kesetaraan gender dan feminisme dalam tayangan program talkshow. Peran media tidak dapat dilepaskan dalam melanggengkan hegemoni sistem patriarki pada satu sisi, dan menyebarkan wacana tentang feminisme di sisi lain.

Menurut Hermes (2007), kita perlu memahami bagaimana media menampilkan isu tentang kesetaraan gender karena 'konstruksi feminitas dan maskulinitas merupakan bagian dari ideologi dominan' (McQuail, 2011). Hal ini menjadi lebih dalam dan luas daripada agenda aslinya yang terbatas, seperti representasi wanita di media, yang direndahkan, dan stereotip dan sosialisasi peranan seksual yang masih menjadi ciri-ciri konten media. Fokus utama adalah peranan gender dalam 'memposisikan' penonton dalam kaitannya dengan gambar pria dan wanita (baik dalam film, foto, televisi).
Feminisme berasal dari kata latin femina yang berarti memiliki sifat keperempuanan. Menurut Hubies, feminisme diawali oleh persepsi tentang ketimpangan posisi perempuan dibanding laki-laki di masyarakat. Akibat persepsi ini, timbul berbagai upaya untuk mengkaji penyebab ketimpangan tersebut dalam mengeliminasi dan menemukan formula penyetaraan hak perempuan dan laki-laki dalam segala bidang, sesuai dengan potensi mereka sebagai human (Diani, Lestari, \& Maulana, 2017).

Secara esensial terdapat empat tipologi teori feminis seperti yang dijelaskan berikut ini (Ritzer \& Goodman, 2004): (1) Posisi dan pengalaman perempuan dari kebanyakan situasi berbeda dari yang dialami lelaki dalam situasi itu; (2) Posisi wanita dalam kebanyakan situasi tak hanya berbeda tetapi juga kurang menguntungkan atau tak setara dibandingkan laki-laki; (3) Situasi wanita harus pula dipahami dilihat dari sudut hubungan kekuasaan langsung antara laki-laki dan wanita; dan (4) Wanita mengalami pembedaan, ketimpangan dan berbagai penindasan berdasarkan posisi total mereka dalam susunan stratifikasi dan hak istimewa-kelas, ras, umur, status perkawinan, dan posisi global.

Argumen perbedaan gender yang kekal ini dipakai untuk melawan perempuan dalam diskursus patriarkis laki-laki untuk mengklaim bahwa perempuan adalah inferior dan tunduk pada laki-laki. Dalam implikasinya yang lebih luas untuk perubahan sosial feminisme kultural mengatakan bahwa cara perempuan dalam menjalani hidup dan mendapatkan pengetahuan 
bisa menjadi model yang lebih baik untuk menghasilkan masyarakat yang adil ketimbang preferensi tradisional dari kultur androsentris laki-laki (Ritzer \& Goodman, 2004).

\section{Representasi, Bahasa dan Kekuasaan}

Untuk memahami konsep pembacaan teks di media, kita diarahkan untuk memahami terlebih dahulu konsep representasi. Representasi ini adalah salah satu praktek penting yang menghasilkan budaya, dimana budaya adalah konsep yang sangat luas, terkait dengan pengalaman berbagi budaya. Seseorang dikatakan berasal dari budaya yang sama jika orang tersebut membagi pengalaman yang sama, membagi kode budaya yang sama, berbicara dalam bahasa yang sama, dan berbagi konsep yang sama.

Menurut Stuart T. Hall (2003), ada dua proses representasi. Pertama, representasi mental, yaitu konsep sesuatu yang telah di kepala kita masing-masing (peta konseptual). Sebuah representasi mental masih berbentuk sesuatu yang abstrak. Kedua, bahasa yang memainkan peran penting dalam proses berarti konstruksi. Konsep abstrak yang di kepala kita harus diterjemahkan dalam bahasa yang lazim, sehingga kita dapat menghubungkan konsep dan ide-ide kita tentang sesuatu dengan tandatanda dan simbol-simbol tertentu. Proses pertama memungkinkan kita untuk menafsirkan dunia dengan membangun rantai korespondensi antara sesuatu dengan sistem peta konseptual (Hall, 2003).
Kedua, kita berada dalam proses membangun rantai korespondensi antara peta konseptual dengan simbol atau bahasa yang berfungsi untuk mewakili konsep tentang sesuatu kami. Hubungan antara "hal-hal", "peta konseptual", dan "bahasa" atau "simbol" adalah inti dari produksi makna melalui bahasa. Proses menghubungkan tiga unsur secara kolektif itulah yang kita sebut representasi. Konsep representasi bisa berubah-ubah. Selalu ada pemaknaan baru dan perspektif baru dalam konsep representasi yang telah ada. Intinya adalah bahwa tidak ada arti yang melekat pada sesuatu di dunia ini, selalu dibangun, diproduksi, melalui proses representasi. Ini adalah hasil dari praktek penandaan tersebut. Praktek sesuatu yang membuat sesuatu yang berarti.

Representasi dalam rangkaian adalah salah satu dari proses budaya (sirkuit budaya). Melalui perwakilan, maka artinya dapat melayani dan akhirnya terungkap. Representasi disampaikan melalui tanda-tanda. Tanda-tanda seperti suara, kata-kata, menulis, ekspresi, sikap, fashion, dan sebagainya adalah bagian dari dunia materi kita (Hall, 2003). Tanda-tanda ini adalah media yang membawa makna tertentu dan mewakili makna tertentu ingin disampaikan kepada dan oleh kami. Melalui tanda-tanda ini, kita dapat mewakili pikiran, perasaan, dan tindakan kita.

Bahasa dalam perspektif kritis tidak dimaknai sebagai sesuatu yang netral yang dapat mentransmisikan dan menghadirkan 
realitas sosial seperti keadaan aslinya, tetapi bahasa sudah bermuatan kekuasaan. Kesenjangan yang besar antara teks yang sangat mikro dan sempit dengan masyarakat yang luas dan besar. Bahasa tak dapat dilepaskan dari perannya sebagai alat kontrol sosial dan alat kekuasaan. Antara bahasa dengan kekuasan terdapat jarak atau celah untuk menghadirkan kekuatan-kekuatan dalam teks. Bahasa juga dapat dijadikan alat untuk mendeteksi ideologi dalam teks, karena ideologi berhubungan erat dengan kekuasaan. Dan ideologi juga dekat dengan bahasa, karena penggunaan bahasa adalah bentuk paling umum dari kebiasaan sosial (Fairclough, 2001).

Konsepsi tentang bahasa yang berhubungan dengan kekuasaan adalah wacana (discourse), ditentukan oleh konstitusi sosial berupa seperangkat konvensi yang berubungan dengan institusi-institusi sosial (Fairclough, 2001). Fenomena bahasa terjadi ketika orang berbicara, mendengarkan, menulis, atau membaca, dimana mereka dipengaruhi oleh oleh masyarakat dan akan berdampak kepada masyarakat itu pula.

Dalam kehidupan politik kenegaraan, kekuasaan seseorang atau mereka yang berkuasa, menyebar bukan sekadar melalui alatalat politik dan birokrasi. Kekuasaan dan ideologi secara lebih jauh dan efektif menyebar dan diaktualisasikan melalui bahasa.

Bahasa yang dipakai seringkali mencerminkan bangunan dan proses kekuasaan yang dominan. Sebagaimana disampaikan Habermas (1984), bahwa bahasa adalah kepentingan. Kepentingan dari siapa yang memakainya. Dan mereka yang memiliki kekuasaan juga menguasai bahasa, yakni bahasa yang membawa kepentingan kekuasaannya (Habermas, 1984).

Melalui bahasa, kekuasaan dapat semakin dikumpulkan atau semakin berpengaruh ke segala arah. Pelaku dapat diubah menjadi objek dan objek diubah menjadi subjek. Sesuatu yang secara subtansi inkonstitusional dapat berubah menjadi konstitusional dan begitu pula sebaliknya. Semua itu dapat terjadi karena kekuasaan yang telah menemukan saluran melalui bahasa.

\section{METODE PENELITIAN}

Desain yang digunakan dalam penelitian ini adalah desain penelitian kualitatif dengan pendekatan analisis wacana kritis. Metode penelitian kualitatif merupakan suatu penelitian yang memahami fenomena tentang apa yang dialami oleh subjek penelitian misalnya prilaku, motivasi, tindakan, dan lain-lain secara holistik dan dengan cara deskripsi dalam bentuk katakata dan bahasa pada suatu konteks khusus yang alamiah serta dengan memanfaatkan berbagai metode alamiah. Pada penelitian ini, peneliti mengkaji aspek kebahasaan dan konteks sosiokultural yang tersirat pada program acara televisi Satu Indonesia yang berhubungan dengan kuasa media untuk memilih wacana dan isu gender dengan menggunakan pisau bedah analisis wacana kritis Norman Fairclough.

Teknik analisis data pada penelitian ini adalah menggunakan analisis analisis wacana kritis pendekatan Norman Fairclough, yang melibatkan tiga tingkat analisis: (1) analisis teks 
atau textual (mikro), yaitu pendeskripsian (description) mengenai teks; (2) analisis wacana atau discourse practice (meso), yaitu interpretasi (interpretation) hubungan antara proses produksi wacana dan teks; (3) analisis sosiobudaya atau sociocultural practice (makro), yaitu penjelasan (explanation) hubungan antara proses wacana dengan proses sosial (Fairclough, 2001); (Fairclough, 2010). Teknik analisis ini berguna untuk mencari tahu bagaimana relasi kuasa media dan representasi isu gender ada dalam tayangan Satu Indonesia episode Sultan Hamengkubuwono X.

Setelah mendapatkan data penelitian, kemudian peneliti menganalisis sesuai dengan fokus penelitian dan tujuan penelitian. Analisis dilakukan dengan cara memilih beberapa bagian dari scene pada program televisi ini, kemudian peneliti melakukan trans-literasi terhadap beberapa adegan tersebut untuk selanjutnya dianalisis dengan analisis wacana kritis model Norman Fairclough untuk memperoleh hasil yang diinginkan.

\section{HASIL DAN PEMBAHASAN}

Hasil Transliterasi Teks Acara Satu Indonesia Episode Sultan Hamengku

\section{Buwono X}

Dari rekaman dialog yang terjadi dalam program acara Satu Indonesia di NET.TV episode Sultan Hamengku Buwono X, dilakukan transliterasi percakapan yang berkaitan dengan isu seputar suksesi di Yogyakarta untuk mendapatkan teks bahasa yang dapat dianalisis. Adapun hasil transliterasi tersebut disajikan dalam tabel berikut :

Tabel 1 Hasil Transliterasi

\begin{tabular}{|c|c|c|}
\hline No & Aktor Sosial & Pernyataan \\
\hline 1 & $\begin{array}{l}\text { Interviewer } \\
\text { (Media) }\end{array}$ & $\begin{array}{l}\text { Bagaimana keluarga } \\
\text { menyikapi soal pengganti } \\
\text { Sultan nanti? }\end{array}$ \\
\hline 2 & GKR Hemas & $\begin{array}{l}\text { Bagi saya itu adalah hak } \\
\text { prerogratif beliau sebagai } \\
\text { Sultan siapapun nanti yang } \\
\text { akan menggantikan beliau }\end{array}$ \\
\hline 3 & $\begin{array}{l}\text { GKR } \\
\text { Pembayun }\end{array}$ & $\begin{array}{l}\text { Tetapi kami di dalam } \\
\text { keluarga belum pernah ada } \\
\text { pembahasan seperti itu } \\
\text { (pengganti Sultan HB X) }\end{array}$ \\
\hline 4 & Sulan HB X & $\begin{array}{l}\text { Sistem pendidikan yang } \\
\text { dibangun keraton memiliki } \\
\text { kekurangan, karena laki- } \\
\text { laki jauh lebih mandiri } \\
\text { dibandingkan anak-anak } \\
\text { perempuan. Sehingga } \\
\text { anak-anak perempuan } \\
\text { lebih baik belajar ke luar } \\
\text { negeri }\end{array}$ \\
\hline 5 & $\begin{array}{l}\text { Interviewer } \\
\text { (Media) }\end{array}$ & $\begin{array}{l}\text { Sultan mempunyai } 5 \text { anak } \\
\text { perempuan, kemudian } \\
\text { nanti menurut Sultan } \\
\text { siapa? }\end{array}$ \\
\hline 6 & Sultan HB X & $\begin{array}{lr}\text { Jika } & \text { masyarakat } \\
\text { menghendaki } & \text { laki-laki } \\
\text { mungkin itu bisa terjadi. } \\
\text { Tapi jika masyarakat } \\
\text { sekarang } & \text { menghargai } \\
\text { wanita berperan di } \\
\text { masyarakat } \\
\text { sesuatu sebagai } \\
\text { berproses, silahkan. Saya } \\
\text { belum bisa menentukan. }\end{array}$ \\
\hline 7 & $\begin{array}{l}\text { Interviewer } \\
\text { (Media) }\end{array}$ & $\begin{array}{l}\text { Jika laki-laki berarti siapa } \\
\text { yang akan mendapatkan? }\end{array}$ \\
\hline 8 & Sultan HB X & $\begin{array}{l}\text { Saya juga tidak akan } \\
\text { pernah } \\
\text { Faktor-faktor tertentu juga } \\
\text { jadi pertimbangan. Faktor } \\
\text { masyarakat punya } \\
\text { pandangan bisa menjadi } \\
\text { tauladan atau tidak, secara } \\
\text { visi dan pikiran dia normal } \\
\text { atau tidak. Resistensi ada }\end{array}$ \\
\hline
\end{tabular}




\begin{tabular}{|c|c|c|}
\hline & & $\begin{array}{l}\text { tidak. Bagaimanapun } \\
\text { jaman sudah berubah }\end{array}$ \\
\hline 9 & $\begin{array}{l}\text { Interviewer } \\
\text { (Media) }\end{array}$ & $\begin{array}{l}\text { Saya juga masih penasaran } \\
\text { dengan penerus keraton } \\
\text { ini, karena saya pernah } \\
\text { dengar kalau Sultan bicara } \\
\text { kalau memang perempuan } \\
\text { itu dibutuhkan ya tidak } \\
\text { apa-apa, memang apa } \\
\text { bedanya antara perempuan } \\
\text { dan laki-laki. Tapi ada } \\
\text { yang mengatakan bahwa } \\
\text { Sultan itu harus menjadi } \\
\text { imam juga }\end{array}$ \\
\hline 10 & Sultan HB X & $\begin{array}{l}\text { Posisi keraton sekarang } \\
\text { tidak seperti dulu, dulu } \\
\text { bentuk pemerintahan, } \\
\text { berarti ada wewenang yang } \\
\text { luas termasuk kepada } \\
\text { rakyatnya sendiri. } \\
\text { Sekarang itu keraton hanya } \\
\text { pelestari budaya, bukan } \\
\text { bicara politik lagi, bukan } \\
\text { bicara kekuasaan lagi }\end{array}$ \\
\hline 11 & Sultan HB X & $\begin{array}{l}\text { Sultan apapun gelarnya } \\
\text { Sultan atau Sunan hanya } \\
\text { kepala keluarga di dalam } \\
\text { suatu konteks klan } \\
\text { tertentu. Keraton itu hanya } \\
\text { artefak, yang berperan itu } \\
\text { yang di dalam keraton, } \\
\text { karena di situ ada } \\
\text { kehidupan } \\
\text { manusianya }\end{array}$ \\
\hline
\end{tabular}

\section{Analisis Level Mikro (Teks)}

Dari berbagai alat kebahasaan yang digunakan NET.TV dalam program acara dialog "Satu Indonesia" episode Sultan hamengku Buwono $\mathrm{X}$, terdapat tiga alat yang menandai representasi tokoh yang terlibat dalam acara tersebut di atas. Pertama, kohesi dan koherensi, yang ditujukan untuk menunjukkan cara klausa dibentuk hingga menjadi kalimat, dan cara kalimat dibentuk hingga membentuk satuan yang lebih besar. Jalinan dalam analisis ini dapat dilihat melalui penggunaan leksikal, pengulangan kata (repetisi), sinonim, antonim, kata ganti, kata hubung, dan lain-lain. Di bawah ini adalah analisis dari aspek kebahasaan tersebut.

Penggunaan diksi "pengganti Sultan", "siapa yang akan mendapatkan" dan "penerus keraton" dipilih NET.TV untuk menyampaikan pertanyaan tentang suksesi kepemimpinan di Keraton Yogyakarta secara jelas dan gamblang. Dari sini terlihat bagaimana NET.TV sebagai media mencoba untuk menggali informasi tentang suksesi kepemimpinan di Yogyakarta dan menyajikannya langsung ke khalayak agar informasi tersebut dapat dengan mudah diterima masyarakat.

Selain itu, dalam acara ini juga ditampilkan kepada khalayak beberapa kata yang mengandung makna konotasi (metafora) atau kata yang memiliki padanan kata lain, seperti 'hak prerogratif", "membangun wacana sendiri", dan "resistensi". Kata-kata tersebut digunakan untuk membangun opini dalam masyarakat tentang permasalahan suksesi kepemimpinan di Yogyakarta. Kata-kata dan idiom di atas dapat dilihat dalam beberapa kalimat pertanyaan yang disampaikan oleh interviewer seperti "Bagaimana keluarga menyikapi soal pengganti Sultan nanti?" dan "Jika laki-laki berarti siapa yang akan mendapatkan?"

Selain itu, juga terdapat dalam kalimatkalimat jawaban dari pihak keluarga Sultan yaitu GKR Hemas (istri Sultan HB X) dan GKR Pembayun (anak pertama Sultah HB X). Kalimat-kalimat itu antara lain "Bagi saya itu adalah hak prerogratif beliau sebagai Sultan 
siapapun nanti yang akan menggantikan beliau”. Dan "Memang banyak sekali yang bertanya kepada saya dan kemudian membangun wacana sendiri. Tetapi kami di dalam keluarga belum pernah ada pembahasan seperti itu”.

Analisis tata bahasa dalam analisis kritis lebih ditekankan pada sudut klausa yang terdapat dalam wacana. Klausa ini dianalisis dari sudut ketransitifan, tema, dan modalitasnya. Ketransitifan dianalisis untuk mengetahui penggunaan verba yang mengkonstruksi klausa apakah klausa aktif atau klausa pasif, dan bagaimana signifikasinya jika menggunakan nominalisasi. Penggunaan klausa aktif, pasif, atau nominalisasi ini berdampak pada pelaku, penegasan sebab, atau alasanalasan pertanggungjawaban dan lainnya.

Contoh penggunaan klausa aktif senantiasa menempatkan pelaku utama, dalam hal ini Sultan HB X, GKR Hemas, dan Pembawa Acara (Host) sebagai tema di awal klausa. Beberapa kalimat yang menggunakan klausa aktif untuk menonjolkan peran pelaku utama dalam dialog ini adalah pernyataan dari GKR Hemas "Bagi saya itu adalah hak prerogratif beliau sebagai Sultan siapapun nanti yang akan menggantikan beliau”. Kemudaian pernyataan dari Sultan HB X "Saya belum bisa menentukan”, "Saya juga tidak akan pernah mengatakan. Faktor-faktor tertentu juga jadi pertimbangan." Dan pertanyaan dari pembawa acara "Saya juga masih penasaran dengan penerus keraton ini".
Sementara itu unsur tema merupakan analisis terhadap tema yang bertujuan untuk melihat strkutur tematik suatu teks. Dalam analisis ini dianalisis tema yang muncul dan latar belakang kemunculannya. Representasi ini berhubungan dengan bagian mana dalam kalimat yang lebih menonjol dibandingkan dengan bagian yang lain. Dalam unsur tema ini tema tentang suksesi kepemimpinan di Yogyakarta yang paling mendominasi dalam dialog.

Sedangkan modalitas digunakan untuk menunjukkan pengetahuan atau level kuasa suatu ujaran. Fairclough melihat modalitas sebagai pembentuk hubungan sosial yang mampu menafsirkan sikap dan kuasa. Contohnya adalah penggunaan modalitas pada wacana tentang kepemimpinan yang pada umumnya akan didapati mayoritas modalitas yang memiliki makna perintah dan permintaan seperti modalitas mesti, harus, perlu, hendaklah, menghendaki dan lain-lain. Analisis tema ini dapat dilihat dalam kalimat yang disampaikan Sultan HB $X$ “Jika masyarakat menghendaki laki-laki mungkin itu bisa terjadi. Tapi jika masyarakat sekarang menghargai wanita berperan di masyarakat sebagai sesuatu kekuatan berproses, silahkan. Saya belum bisa menentukan", dan "Saya juga tidak akan pernah mengatakan". Sultan HB X "Publik itu butuh pemimpin yang perlu bisa diyakini, tetapi di satu pihak pemimpin itu juga bagaimana dia bisa bertindak untuk bisa dipercaya rakyat". 


\section{Analisis Level Meso (Wacana)}

Stasiun televisi NET.TV adalah salah satu televisi free to air yang masih baru di kancah pertelevisian Indonesia. NET.TV yang merupakan singkatan dari News and Entertainment Television resmi diperkenalkan pada publik pada 26 Maret 2013. Pangsa pasar yang dibidik NET.TV adalah keluarga dan pemirsa muda. Jaringan terestrial yang dimiliki NET.TV merupakan hasil akuisisi saham kepemilikan PT. Televisi Anak Spacetoon oleh PT. NET Mediatama dan Group Indika pada Maret 2013. Di bawah bendera PT. NET Mediatama, NET.TV merombak total program tayangan Spacetoon menjadi beberapa program acara yang langsung mendapatkan perhatian penonton televisi di Indonesia.

Keberagaman program acara dan kreativitas kru NET.TV untuk menayangkan acara-acara yang "berbeda" dengan stasiun televisi lain menjadikan NET.TV sebagai salah satu stasiun televisi paling diminati di Indonesia. Di bawah kepemimpinan Direktur Utama Wishnutama yang pernah bergabung di Trans Group, dan Agus Lasmono sebagai Komisaris Utama yang juga pernah menjadi Komisaris Independen di SCTV, saat ini NET.TV telah berkembang dengan pesat. Dengan misi menjadi media televisi yang lebih maju dan modern, NET.TV telah menjadi "mesin ekonomi” bagi para pemilik modal.

Wacana kesetaraan gender sebagai praktik sosial dalam konteks suksesi kepemimpinan di Yogyakarta dipilih oleh NET.TV dalam program acara ini. Sebagai media massa, NET.TV lebih mengedepankan pertanyaan-pertanyaan seputar isu gender ketika melakukan wawancara dengan nara sumber acara. Bahasa yang digunakan oleh presenter acara Satu Indonesia merepresentasikan dinamika yang terjadi di Yogyakarta terkait pergantian Sultan, ketika Sultan HB X tidak memiliki anak laki-laki. Dalam hal ini, NET.TV memiliki kuasa untuk memilih wacana yang akan disampaikan kepada khalayak terkait isuisu yang berkembang di dalam masyarakat.

Dari unsur genre atau bagaimana media melakukan tindakan (ways of acting) terlihat NET.TV memfokuskan isu gender sebagai bahasan utama dalam acara yang mewawancarai Sultan HB $\mathrm{X}$ sebagai narasumber utama, dan GKR Hemas serta GKR Pembayun sebagai narasumber pendukung. Sedangkan dari bagaimana media melakukan representasi (ways of representing), dari analisis level teks di atas secara jelas NET.TV melalui pembawa acara yang sekaligus interviewer banyak menggunakan kalimat-kalimat yang mengarah pada isu kesetaraan gender dan dinamika demokrasi dalam konteks keraton Yogyakarta sebagai lembaga budaya dan politik.

\section{Analisis Level Makro (Soiso-Kultural)}

Situasi sosial politik yang terjadi saat penayangan program acara Satu Indonesia Episode Sultan Hamengku Buwono X pada November 2014 ini tidak dapat dilepaskan konteks yang membangun program acara tersebut. Seperti kita ketahui bersama bahwa sepanjang tahun 2014 berlangsung pemilihan umum legislatif dan pemilu presiden, yang akhirnya menghasilkan wakil-wakil rakyat dan 
pemimpin baru di Indonesia. Seluruh peristiwa tersebut mendapat liputan yang luas dari berbagai media yang ada di Indonesia termasuk NET.TV.

Selain hal tersebut di atas, situasi politik dalam kaitannya dengan pemberitaan di atas adalah bahwa pada saat penayangan acara ini berlangsung, situasi politik Indonesia sedang menghangat menjelang Pemilihan Umum Kepala Daerah (Pilkada) serentak tahun 2015. Dalam konteks Daerah Istimewa Yogyakarta, yang tidak mengenal pemilihan kepala daerah (gubernur) secara langsung menjadi menarik bagi masyarakat. Sesuai dengan ketentuan dalam Undang-Undang Nomor 13 Tahun 2012 tentang Keistimewaan Yogyakarta, disebutkan bahwa Gubernur dan Wakil Gubernur DIY adalah orang yang berkedudukan sebagai Sultan di Kasultanan Yogyakarta dan Adipati Paku Alam di Puro Pakualaman.

Keistimewaan Yogyakarta ini menjadi menarik diperbincangkan ketika Sultan Hemengku Buwono X tidak memiliki anak lakilaki sebagai pewaris tahta keraton Yogyakarta, sekaligus penerus kekuasaan politik sebagai Gubernur di DIY. Hal ini menimbulkan pertanyaan dan memancing opini masyarakat luas tentang siapa yang akan menggantikan kedudukan Sultan Hamengku Buwono X jika kelak beliau meninggal dunia. Opini para bangsawan Keraton Yogyakarta dan rakyat Yogyakarta menjadi terpecah dalam dua kubu. Pihak pertama tidak mempermasalahkan apabila penerus tahta Kasultanan Yogyakarta adalah putri sulung Sultan HB X, yakni GKR Pembayun. Namun pihak yang lain menentang pendapat tersebut, karena sesuai dengan adat dan kebiasaan turun temurun di Kasultanan Yogyakarta, raja Kasultanan Yogyakarta adalah sekaligus imam agama islam bagi rakyat Yogyakarta, yang berarti harus seorang lakilaki.

Permasalahan pergantian kepemimpinan di Yogyakarta ini menjadi rumit karena orang yang menjadi pengganti Sultan HB $X$ akan memegang dua kekuasaan sekaligus. Sebagai raja Kasultanan Yogyakarta, Sultan adalah penguasa kultural, sekaligus sebagai Gubernur Daerah Istimewa Yogyakarta yang memegang kekuasaan politik. Dalam hal ini, seiring berjalannya waktu Sultan HB X dalam beberapa kesempatan menyampaikan bahwa Kasultanan Yogyakarta harus dapat mengikuti perkembangan jaman, dimana Kasultanan Yogyakarta sebagai bagian dari Negara Republik Indonesia harus tunduk pada ketentuan konstitusi yang berlaku. Sultan HB X juga meminta masyarakat Yogyakarta seharusnya dapat terbuka dalam menerima demokrasi dan kesetaraan gender, dimana wanita mempunyai hak untuk menjadi pemimpin.

Meski tidak berkaitan secara langsung, tetapi dapat ditarik benang merah atas penayangan program acara ini di NET.TV, erat kaitannya dengan keberadaan NET.TV sebagai media nasional yang memiliki kepentingan ekonomi. Daerah Istimewa Yogyakarta adalah 
salah satu wilayah potensial bagi tayangan acara NET.TV, karena di Yogyakarta berkumpul ribuan mahasiswa dan pelajar dari seluruh provinsi di Indonesia. Yogya adalah miniatur Indonesia yang bernilai ekonomi dan politik sangat tinggi. Dengan menguasai pasar Yogyakarta, NET.TV akan semakin dikenal dan berkembang. Inilah mengapa dalam tayangan Satu Indonesia Episode Sultan HB X, NET.TV berusaha untuk menampilkan Sultan dalam posisi terbaik sebagai Gubernur DIY dan Raja Kasultanan Yogyakarta.

Televisi nasional adalah "panggung" bagi setiap orang untuk tampil dan dilihat masyarakat. Dengan tampil pada acara ini, Sultan Hamengku Buwono X diberikan panggung untuk menyampaikan opini dan pendapatnya tentang suksesi kepemimpinan di Yogyakarta. Dengan format semi-dokumenter, Satu Indonesia dapat leluasa memberikan ruang bagi Sultan HB $X$ untuk membeberkan pembenaran-pembenaran atas kepemimpinan kaum perempuan dengan dalih modernisasi, feminisme, dan demokrasi.

Dari analisis wacana kritis terhadap program acara Satu Indonesia episode Sultan Hamengku Buwono X di atas dapat dilakukan pembahasan dengan menggunakan landasan teori yang telah disampaikan sebelumnya. Dari sudut pandang teori bahasa, wacana dan kekuasaan. Melalui bahasa, kekuasaan dapat semakin dikumpulkan atau semakin berpengaruh ke segala arah. Pelaku dapat diubah menjadi objek dan objek diubah menjadi subjek. Sesuatu yang secara subtansi inkonstitusional dapat berubah menjadi konstitusional dan begitu pula sebaliknya. Semua itu dapat terjadi karena kekuasaan yang telah menemukan saluran melalui bahasa.

Dalam permasalahan penelitian ini, dapat kita lihat bagaimana seorang Sultan menggunakan bahasa yang bertolak belakang dengan kenyataan yang sebenarnya. Seperti dalam kutipan wawancara acara Satu Indonesia episode Sultan HB X dimana beliau mengatakan bahwa "Posisi keraton sekarang tidak seperti dulu, dulu bentuk pemerintahan, berarti ada wewenang yang luas termasuk kepada rakyatnya sendiri. Sekarang itu keraton hanya pelestari budaya, bukan bicara politik lagi, bukan bicara kekuasaan lagi”. Dari petikan wawancara tersebut, dapat dilihat bahwa Sultan menyampaikan posisi keraton Yogyakarta yang tidak memiliki kewenangan secara politis. Padahal posisi Sultan sebagai raja Kasultanan Yogyakarta sesuai ketentuan Undang-Undang No. 13 Tahun 2012 tentang Keistimewaan Yogyakarta, Sultan adalah sekaligus Gubernur Daerah Istimewa Yogyakarta, dimana jabatan Gubernur di DIY sama dengan di daerah lain di Indonesia, yaitu sebagai pemegang kekuasaan politik di provinsi.

Kekuasaan dan politik juga seringkali bermain dengan dalam tataran klaim atau pengakuan. Dalam permasalahan suksesi kepemimpinan di Yogyakarta ini muncul pula klaim bahasa, yakni bahasa yang membawa muatan kepentingan kekuasaan. Klaim atas nama masyarakat dan kesetaraan hak laki-laki dan perempuan dapat ditemukan dalam dialog yang terjadi pada acara ini, yaitu "Jika masyarakat menghendaki laki-laki mungkin itu 
bisa terjadi. Tapi jika masyarakat sekarang menghargai wanita berperan di masyarakat sebagai sesuatu kekuatan berproses, silahkan". Dari penggunaan bahasa pada kalimat tersebut, seolah-olah Sultan memberikan pembenaran atas nama rakyat dan peran serta perempuan dalam kehidupan masyarakat, termasuk untuk menjadi seorang pemimpin.

\section{SIMPULAN}

Hasil penelitian menunjukkan bahwa aspek kebahasaan berupa diksi, penggunaan kalimat, dan pemilihan tata bahasa yang digunakan NET.TV telah menempatkan tema mengenai suksesi kepemimpinan di Yogyakarta yang berkaitan dengan isu kesetaraan gender sebagai sesuatu yang tak perlu dirisaukan seluruh kalangan masyarakat. Selain itu aspek kebahasaan juga telah menempatkan tokoh Sultan dan institusi keraton dan Gubernur dalam representasi yang positif. Hal ini erat kaitannya dengan penggunaan bahasa dan penguasaan wacana menjadi alat bagi penguasa untuk melanggengkan hegemoninya. Media, dalam hal ini televisi sebagai lembaga profit yang memiliki kepentingan ekonomi tidak akan pernah lepas dari hitungan laba dan rugi. Dengan memberikan panggung bagi tokoh seperti Sultan Hamengku Buwono X, NET.TV berharap kepentingan ekonominya di Daerah Istimewa Yogyakarta dapat terjaga dan terkendali dengan terjalinnya hubungan baik dengan penguasa daerah.

\section{DAFTAR PUSTAKA}

Diani, A., Lestari, M. T., \& Maulana, S. (2017). Representasi Feminisme Dalam Film Maleficent. ProTVF: Jurnal Kajian Televisi Dan Film, 1(2).

Fairclough, N. (2001). Language and Power. London: Pearson Education Limited.

Fairclough, N. (2010). Critical Discourse Analysis: The Critical Study of Language. London: Pearson Education Limited.

Habermas, J. (1984). Theory of Communicattive Action. Boston: Beacon.

Hall, S. T. (2003). Representation. London: SAGE Publications.

Maulana, A., \& Nugroho, C. (2018). Nasionalisme Dalam Narasi Cerita Film (Analisis Narasi Tzvetan Todorov Pada Film Habibie \& Ainun). ProTVF: Jurnal Kajian Televisi Dan Film, 2(1), 37-49.

McQuail, D. (2011). Teori Komunikasi Massa McQuail. Jakarta: Salemba Humanika.

Ritzer, G., \& Goodman, D. J. (2004). Teori Sosiologi Modern. Jakarta: Kencana Prenadamedia Group. 